\title{
Analysis and Identification of the Value of Anti- Corruption Education in Indonesian Traditional Games
}

\author{
Auliya Aenul Hayati*, Dede Trie Kurniawan \\ PGSD FKIP \\ Universitas Swadaya Gunung Jati Cirebon \\ Cirebon, Indonesia \\ *auliyaaenul@gmail.com,dhe3kurniawan@gmail.com
}

\begin{abstract}
Corruption behavior has become a problem that needs to be solved so that it does not become a culture in Indonesia. One way to install anti-corruption values is by the game method because according to $\mathrm{J}$. Piaget Games is the way children work - their understanding of knowledge. Traditional games can be implemented by utilizing a tactical approach teaching model (teaching games to understand) so that children understand what and why the purpose of the game is done. The results of research that have been conducted found that the traditional games of elementary school students have been shown to increase students' understanding of anti-corruption values by playing methods for anti-corruption values such as honesty, discipline, responsibility, courage, attention, hard work, simple, independent and fair. One reason they understand the value of anti-corruption is the existence of strict social sanctions that are disliked by children in the form of sanctions that are alienated and do not want to be friends because of cheating.
\end{abstract}

Keywords: traditional games, anti-corruption values, values education, basic education

\section{INTRODUCTION}

One of the problems faced by the Indonesian people is corruption [1]. Corruption in Indonesia develops systematically for many people corruption is no longer a violation of the law. but just a habit. In all comparative studies of corruption between Indonesian countries always occupy the lowest position [1]. This situation could lead to an increase in corruption eradication in Indonesia by the authorities. The development of corruption in Indonesia also encourages the eradication of corruption in Indonesia [1,2]. But until now the eradication of corruption in Indonesia has not shown a bright spot seeing the ranking in the ratio of corruption between countries that remains low [2]. This is also shown from the number of corruption cases in Indonesia. Actually, the authorities like KPK (Corruption Eradication Commission) have tried to do the maximum work. But the work to be done is far more than the energy and time of the KPK.

In Indonesia that corruption has become a culture, if so corruption cannot be said to be an extraordinary crime, but on the contrary but an ordinary crime caused by the main reason that the government's efforts through the prosecutor and the
Corruption Eradication Commission (KPK) to eradicate corruption do not get significant results, even costs The state for the purpose of eradication is proven to be twice as big as the state money returned by the two institutions [2]. The second reason is the increasing number of corruptors. The proposed change in the preventive strategy as an alternative to complementing the enforcement strategy proves that there has been a failure of fission and mission contained in RI Law No. $31 / 1999$ which was changed to RI Law No. 20/2001 on Eradication of Corruption (Corruption). With the main aim of returning and saving the State finances.

From these reasons, it proves that the vision and mass of the objectives of the establishment of anti-corruption legislation and the reversed character of the characters that have been attached to the law have been tarnished or defiled by certain elements. Investors collaborate with personal interests or certain groups to benefit both material and immaterial. In the problem and the root cause of the corruption turns out to be in each of us [3]. Want to follow the strong current to enrich themselves legally or illegally, legally or illegally, and honestly or not. It turns out that there are many choices for the same purpose but different ways between each of us. The state of the problem of corruption is not merely a matter of the political component, but also all levels of society blame more, but also forget the fallacy of education from elementary school through college [3]

Efforts made to eradicate this corrupt phenomenon can begin in our immediate environment, namely the family. Parents must educate their children about the bad things that corruption causes [4]. Parents also need to instill good morals in their children so that corrosive mentality and all kinds of other bad mentalities do not grow [3,5,6].

Education in primary schools is the education of children aged between 7-12 years as basic level education which is developed in accordance with the regional potential education unit or regional characteristics, social culture of the local community for students [7]. This is where elementary school students are forged in various fields of study all of which must be able to be mastered by students. It is not wrong if elementary school is called an education center, not only in the 
classroom the learning process that occurs but outside the classroom is also included in learning activities [7]. At the age of elementary school children, children are considered to be most physically ready. To stay in class until noon. The child's motor movements have better muscles and nerves have also formed. In this case the characters of elementary school age children basically still like to play [6].

The game can be done as a learning activity when the activity is outside the scope of the room or outdoor. The application of game media can be used as an alternative to increase student motivation [8]. Many people can think that playing and learning is something that is the opposite, but according to children playing is fun. Many aspects are contained in play especially play that has an educational element. One of the media used in the process of teaching and learning activities is the game media. Games can be a source of learning or learning media if the game aims to achieve educational or learning goals [9].

Efforts that are inculcated in each individual, especially in the character of elementary school age children to prevent corruption can basically eliminate or at least reduce the internal and external factors that cause corruption. Internal factors are determined by the strong or not anti-corruption values embedded in each individual. These anti-corruption values include honesty, independence, discipline, responsibility, hard work, anti-simple values, courage, and justice [4]. The anticorruption values need to be applied by each individual to overcome internal factors so that corruption does not occur [10]. Therefore, these values will support the principles of anticorruption to be well implemented which is instilled since elementary school age children in the game as a learning medium. The game to be studied is a traditional game in Indonesia. The traditional game chosen for the assessment of the corrupt values is the game of Petak umpet, bekel ball and congklak.

\section{MethodS}

The identification of the values of anti-corruption education in traditional games in children is carried out with a literature review. The literature review referred to in this case is the publication of research results obtained from internet libraries. Various research results on several types of traditional games from various regions in Indonesia have their own character education values. A review is conducted to identify what values exist in traditional games. The identification results are displayed in tabular form and then analyzed to obtain the anticorruption education values contained in traditional bebentengan children's games, Petak Umpet, bekel ball and congklak.

\section{RESULTS AND DisCUSSION}

Anti-corruption values that will be understood by students include Honesty, Discipline, Responsibility, Courage, Caring, Hard Work, Simple, Independent, and Fair [3,11]. These values will be familiarized through the rules of the game which will be examined from traditional Indonesian games such as bebentengan, clogs, hide and seek, congklak and rubber band jumping. Table 1 will show the pictures and general rules of play played by children.

TABLE I. PROFILE OF INDONESIAN TRADITIONAL GAMES TO BE ASSESSED FOR THEIR ANTI-CORRUPTION VALUES

\begin{tabular}{|c|c|}
\hline $\begin{array}{c}\text { Name Of } \\
\text { Traditional } \\
\text { Game }\end{array}$ & Visualization of Game Activities \\
\hline Bekel ball & $\begin{array}{l}\text { Bekel is a game of throwing the ball up and catching it } \\
\text { again. But at the same time must take or change the } \\
\text { position of the seeds in accordance with the rules of the } \\
\text { difficulty level that is run. After deciding whose turn to } \\
\text { start first, the game begins by throwing the ball up and } \\
\text { spreading the seeds. After the ball bounces once, the ball } \\
\text { must be taken back. Then, players must take one by one } \\
\text { the seeds that lay directly. After all is taken, the seeds are } \\
\text { spread back and taken this time at the same time two } \\
\text { seeds. And so on until a number of seeds are played. } \\
\text { After taking the seeds directly finished, then now the } \\
\text { player must change the seeds into a certain shape before } \\
\text { being taken. The order of position is the pit (shape like a } \\
\text { chair), ro (opposite the position of the pit), cin (slippery } \\
\text { abbreviation which is a tilted position with no spots on } \\
\text { the surface of the seeds) and peng (stands for } \\
\text { pockmarked, which is tilted with a spot on the surface of } \\
\text { the seeds). The seeds that are used generally amount to } 6 \\
\text { to } 10 \text { seeds. Players will lose their turn if the ball } \\
\text { bounces more than once, can't catch the ball, forgets to } \\
\text { change one of the seeds to a certain position when it } \\
\text { reaches the pit, ro, cin or peng stage, or touches another } \\
\text { seed when taking the seeds that must be taken. The } \\
\text { winner is the one who reaches the highest stage }\end{array}$ \\
\hline Congklak & $\begin{array}{l}\text { Congklak game is done by two people. In the game they } \\
\text { use boards called congklak boards and } 98 \text { ( } 14 \text { x } 7) \text { seeds } \\
\text { called congklak seeds or congklak fruits. Congklak } \\
\text { boards are generally made of wood and plastic, while the } \\
\text { seeds are made of shells, seeds, rocks, marbles or plastic. } \\
\text { On the congklak board there are } 16 \text { holes consisting of } \\
14 \text { small holes facing each other and } 2 \text { large holes on } \\
\text { both sides. Every } 7 \text { small holes on the player's side and } \\
\text { large holes on the right side are considered as belonging } \\
\text { to the player. At the beginning of the game each small } \\
\text { hole is filled with seven seeds. Two players facing each } \\
\text { other, one who starts can choose the hole to be taken and } \\
\text { put one into the hole on his right and so on } \\
\text { counterclockwise. If the seeds run out in a small hole } \\
\text { containing other seeds, he can take the seeds and } \\
\text { continue filling, if finished in his big hole then he can } \\
\text { proceed by selecting the small hole on his side. When } \\
\text { finished in a small hole on the side, he stops and takes all } \\
\text { the seeds on the opposite side. But if it stops in an empty } \\
\text { hole on the opponent's side it stops and gets nothing. The } \\
\text { game is considered finished when no more seeds can be } \\
\text { taken (all seeds are in the big hole of both players). The } \\
\text { winner is the one who gets the most seeds. }\end{array}$ \\
\hline $\begin{array}{l}\text { Petak } \\
\text { Umpet }\end{array}$ & $\begin{array}{l}\text { Petak Umpet is a game where players try to hide while a } \\
\text { player tries to find and find them }\end{array}$ \\
\hline
\end{tabular}

The identification of the values of anti-corruption education in traditional games in children is carried out with a literature review. The literature review referred to in this case is the publication of research results obtained from internet libraries. Various research results on several types of traditional games from various regions in Indonesia have their own character education values. A review is conducted to identify what values exist in traditional games. The identification results are displayed in tabular form and then analyzed to obtain the anticorruption education values contained in traditional 
bebentengan children's games, clogs, hide and seek, congklak and rubber band jumping. The anti-corruption value contained in the game bebentengan, bakakak, hide and seek, congklak and jumping rubber bands are presented in tables 2,3,4,5 and 6.

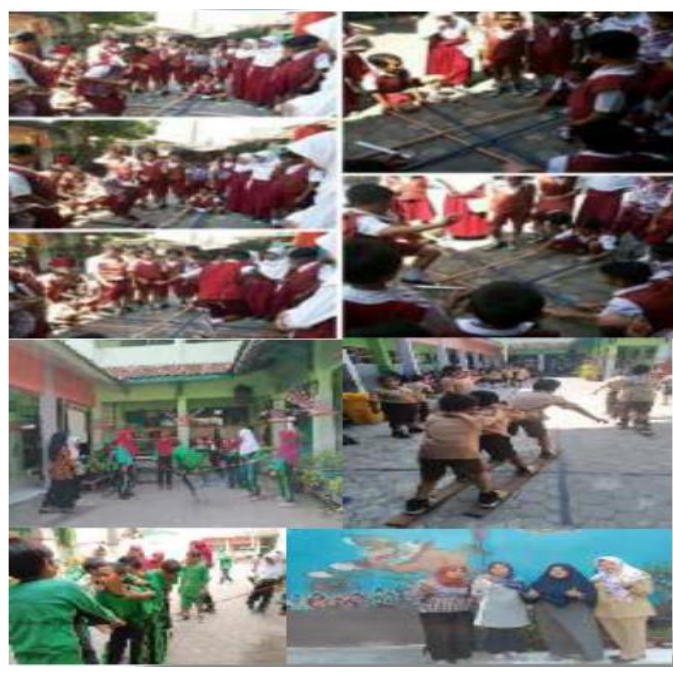

Fig. 1. The games.

TABLE II. FINDINGS OF ANTI CORRUPTION EDUCATION VALEUS IN TRADTIONAL GAMES CONGKLAK

The Emerging Anti-Corruption Education Values

\begin{tabular}{|c|c|c|}
\hline 1 & $\begin{array}{l}\text { The Honesty Aspect that } \\
\text { Appears }\end{array}$ & $\begin{array}{l}\text { Put only one seed in the barn } \\
\text { house itself }\end{array}$ \\
\hline 2 & $\begin{array}{l}\text { Concerns of concern that } \\
\text { arise }\end{array}$ & $\begin{array}{l}\text { Divide the seeds into the } \\
\text { opponent's pit }\end{array}$ \\
\hline 3 & $\begin{array}{l}\text { Independent Aspects That } \\
\text { Appear }\end{array}$ & $\begin{array}{l}\text { Solve problems by thinking alone } \\
\text { without the influence of others }\end{array}$ \\
\hline 4 & $\begin{array}{l}\text { Discipline Aspects That } \\
\text { Appear }\end{array}$ & $\begin{array}{l}\text { Comply with the rules in the } \\
\text { game }\end{array}$ \\
\hline 5 & $\begin{array}{l}\text { Aspects of Responsibility } \\
\text { That Appear }\end{array}$ & Finish the game with a winner \\
\hline 6 & $\begin{array}{l}\text { Hard Work Aspects That } \\
\text { Appear }\end{array}$ & Make a strategy in play \\
\hline 7 & $\begin{array}{lll}\text { Simple } & \text { Aspects } & \text { That } \\
\text { Appear } & & \\
\end{array}$ & $\begin{array}{l}\text { Play together and take turns using } \\
\text { the play tool. }\end{array}$ \\
\hline 8 & $\begin{array}{l}\text { The Courage Aspect that } \\
\text { Appears }\end{array}$ & $\begin{array}{l}\text { Play to make the decision to leave } \\
\text { the veil alone to move between } \\
\text { the opponents. }\end{array}$ \\
\hline 9 & Emerging Justice aspects & $\begin{array}{l}\text { Divide flat congklak seeds into } \\
\text { barns }\end{array}$ \\
\hline
\end{tabular}

TABLE III. FINDINGS OF ANTI CORRUPTION EDUCATION VALEUS IN TRADTIONAL GAMES BEKEL BALL

\section{The Emerging Anti-Corruption Education Values}

\begin{tabular}{|c|l|l|}
\hline \multicolumn{4}{|c|}{ The Emerging Anti-Corruption Education Values } \\
\hline & $\begin{array}{l}\text { The Honesty } \\
\text { Aspect that }\end{array}$ & $\begin{array}{l}\text { 1. When hitting the ball, someone who plays } \\
\text { when hitting the ball must be honest, not } \\
\text { cheating. If at the time of hitting the ball is not hit } \\
\text { with wood but deviated, the player may not run } \\
\text { which he considers to escape. To give members } \\
\text { the opportunity to their team members to escape } \\
\text { from the post that is located. } \\
\text { 2. The opposing team must focus on showing the } \\
\text { opposing team that is playing by watching that } \\
\text { the opposing players move postal positions in } \\
\text { sequence. } \\
\text { 3. All players should pay more attention to the } \\
\text { exact position of the foot, both for the pitcher and } \\
\text { the hitter. }\end{array}$ \\
\hline
\end{tabular}

Table III. Cont.

\begin{tabular}{|c|c|c|}
\hline 2 & $\begin{array}{l}\text { Concerns of } \\
\text { concern that } \\
\text { arise }\end{array}$ & $\begin{array}{l}\text { Fellow team members should work together to } \\
\text { help get point scores.... }\end{array}$ \\
\hline 3 & $\begin{array}{l}\text { Independent } \\
\text { Aspects That } \\
\text { Appear }\end{array}$ & $\begin{array}{l}\text { 1. Each player must carry out a strategy with self- } \\
\text { awareness. for example, when getting hit it must } \\
\text { be a forward initiative and everyone is in the post } \\
\text { when there is an opportunity to run to move to } \\
\text { another post then it must quickly move position } \\
\text { do not wait for the instructions of his friend. }\end{array}$ \\
\hline 4 & $\begin{array}{l}\text { Discipline } \\
\text { Aspects That } \\
\text { Appear }\end{array}$ & $\begin{array}{l}\text { 1. All team members must obey each of the } \\
\text { prescribed rules. For example, in each post there } \\
\text { is a maximum limit of } 3 \text { people to occupy the } \\
\text { post }\end{array}$ \\
\hline 5 & $\begin{array}{l}\text { Aspects of } \\
\text { Responsibility } \\
\text { That Appear }\end{array}$ & $\begin{array}{l}\text { 1. For the guard team must be swift to take the } \\
\text { ball thrown by the paddle to the extent of the ball } \\
\text { being hit and immediately directs to the target of } \\
\text { the opponent who is running to change position. } \\
2 \text {. At the time of the game there is one member } \\
\text { who was injured due to the blow caused by } \\
\text { directing the ball too hard so that the opponent's } \\
\text { limb should apologize and take responsibility for } \\
\text { his mistakes. }\end{array}$ \\
\hline 6 & $\begin{array}{lr}\text { Hard } & \text { Work } \\
\text { Aspects } & \text { That } \\
\text { Appear } & \end{array}$ & $\begin{array}{l}\text { 1. When playing, the hitter should try to hit the } \\
\text { ball as far as possible so that his team members } \\
\text { can escape from the post to enter the finish line to } \\
\text { get points }\end{array}$ \\
\hline 7 & $\begin{array}{l}\text { Simple } \\
\text { Aspects That } \\
\text { Appear }\end{array}$ & $\begin{array}{l}\text { 1. In this game using simple equipment, which is } \\
\text { very easy to find everyone. Like, wooden sticks } \\
\text { and balls. }\end{array}$ \\
\hline 8 & $\begin{array}{l}\text { The Courage } \\
\text { Aspect that } \\
\text { Appears }\end{array}$ & $\begin{array}{l}\text { 1. In this game every player must dare to change } \\
\text { positions by running fast and don't be afraid if } \\
\text { someone directs the ball to us. } \\
2 \text {. For the guard team if you want to direct the } \\
\text { ball to the opponent do not hesitate, according to } \\
\text { the specified pitching technique. }\end{array}$ \\
\hline 9 & $\begin{array}{l}\text { Emerging } \\
\text { Justice aspects }\end{array}$ & $\begin{array}{l}\text { 1. In this game, players are taught justice to their } \\
\text { fellow friends, because each player gets a turn to } \\
\text { hit and throw the ball }\end{array}$ \\
\hline
\end{tabular}

TABLE IV. FINDINGS OF ANTI CORRUPTION EDUCATION VALEUS IN TRADTIONAL GAMES PETAK UMPET

The Emerging Anti-Corruption Education Values

1 The Honesty Aspect that When it has been found by the Appears $\quad$ "guard" must immediately get out do not hide constantly.

2 Concerns of concern that Fellow friends should pay attention arise $\quad$ (remember) their friends who are hiding

3 Independent Aspects That Hide alone without having to be with Appear $\quad$ other friends

4 Discipline Aspects That Hiding in a timely manner according Appear $\quad$ to the count of the guards

5 Aspects of Responsibility All players follow all the rules in the That Appear game of hide and seek

6 Hard Work Aspects That Able to work hard to find friends \begin{tabular}{l|l} 
Appear & who are hiding
\end{tabular}

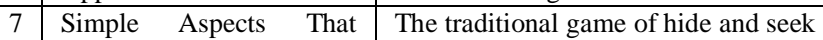
Appear $\quad$ using simple tools

8 The Courage Aspect that Dare to run away with the "guard" in Appears order to get an apple.

9 Emerging Justice aspects $\quad$ Do not discriminate between friends with other friends, despite having closeness in friendship. Suppose a guard finds his friend who is hiding but he pretends as if his closest friend has not been found. 


\section{A. Discussion}

Bekel Ball, Petak Umpet And Congklak are three of the many traditional games which are cultural assets in maintaining the existence and identity that have characteristics in accordance with the characteristics of elementary school students [12].

Actions taken routinely and continuously by students will help the child's brain record these actions as a concept of behavior in life. In the case of traditional rules that are routinely played, a pattern can be made: a player who continually cheats in the game will experience pressure in the form of guilt from other team members because the result of his cheating makes his team unable to participate in the next 1 (one) match. The emergence of guilt and social control playmates create a desire to improve themselves by minimizing the element of cheating during the game. Conditions that continue to repeat until patterned value concepts in the brain so that it can affect motor sensors or controllers of other physical body organs.

Some of the benefits provided are students can interact with the group, physically move the body actively, care for fellow team members, be aware of opposing movements, be trained in decision making in difficult situations, be trained to be honest because cheating results in failure to follow the game in the next time, trained to be able to work together, trained to carry out verbal communication and body language, and train a sense of responsibility for the decisions taken $[12,13]$

In general, students' anti-corruption score beliefs are categorized based on 9 (nine) existing anti-corruption values, namely (1). Honest value, (2). Value of discipline, (3). Value of responsibility, (4). Fair value, (5). Brave value, (6). The value of caring, (7). The value of hard work, (8). Independent value, and (9). Simple value $[3,11]$.

\section{CONCLUSION}

In the comparison of corruption between countries, Indonesia is a global highlight due to the high number of corruptions in the country. This situation could lead to an increase in corruption eradication in Indonesia by the authorities. The development of corruption in Indonesia also encourages the eradication of corruption in Indonesia. But until now the eradication of corruption in Indonesia has not shown a bright spot seeing the ranking in the ratio of corruption between countries which remains low. This is also shown from the number of corruption cases in Indonesia. Efforts made to eradicate this corrupt phenomenon can begin in our immediate environment, namely the family. Parents have to instill good morals in their children so that mental corruption and all kinds of other bad mentality does not grow. Education in primary schools is the education of children aged between 7-12 years as basic level education which is developed in accordance with the regional potential education unit or regional characteristics, social culture of the local community for students. Basically, the characteristics of elementary school students still like to play. Games can be a source of learning or learning media if the game aims to achieve educational or learning goals. Efforts that are inculcated in each individual, especially in the character of elementary school age children to prevent corruption, can basically eliminate or at least reduce the internal and external factors that cause corruption. These anticorrupt values include honesty, independence, discipline, responsibility, hard work, anti-simple values, courage, and justice. These values can be instilled in children's characters from an early age through traditional games as a medium of learning at school [12-14].

\section{ACKNOWLEDGMENT}

The author would like to thank the various parties who have helped in the writing of this paper. This paper was funded by a budding lecturer research (PDP Research) from the Ministry of Research and Technology in 2019 financing.

\section{REFERENCES}

[1] E. Liem, "Masalah Korupsi di Negeri ini," [Online]. Retrieved from https://www.kompasiana.com/riczaricz/5a080984fcf68129a72a6042/ma salah-kosrupsi-di-negeri-ini

[2] Badan Pusat Statistik, Laporan Ringkas Survei Perilaku Anti Korupsi (SPAK) 201 (Indeks Perilaku Anti Korupsi dan Indikator Tunggal). Jakarta: Badan Pusat Statistik, 2012

[3] N.T. Puspito, S.M. Elwina, I.S. Utari, and Y. Kurniadi, Pendidikan Anti Korupsi untuk Perguruan Tinggi. Jakarta: Kemendikbud RI, 2011.

[4] S. Marlina, "Character Values Development in Early Childhood through Traditional Games," 3rd International Conference on Early Childhood Education (ICECE-16), 2017.

[5] R. Kurnia, "Konsepsi Bermain dalam menumbuhkan kreativitas pada anak usia dini," Educhild, vol. 1, no. 1, pp. 77-85, 2012.

[6] Saryono and A. Rithaudin, "Meta Analisis Pengaruh Pembelajaran Pendekatan Taktik (TGfU) Terhadap Pengembangan Aspek Kognitif Siswa Dalam Pendidikan Jasmani," Jurnal Pendidikan Jasmani Indonesia, vol. 8, no. 2, pp. 144-151, 2011

[7] D.M. Putri, "Pembentukan Konsep Diri Anak Usia Dini di One Earth School Bali," Journal Communication Spectrum, vol. 2, no. 1, pp. 100117,2012

[8] S. Azzahra, "Permainan Sebagai Media Pembelajaran," [Online] Retrieved from https://www.kompasiana.com/safirasunmi86/5a01712aa208c002b6730ff 4/permainan-sebagai-media-pembelajaran

[9] D. Rahmawati and R. Destarisa, Aku Pintar Dengan Bermain. Solo: Metagraf, 2016.

[10] P.A. Satwika, M. Supratiwi, F.K. Anggarani, and R. Setyowati, "Permainan tradisional sebagai bentuk promotif nilai anti korupsi anak usia dini," WACANA, vol. 9, no. 2, 2017.

[11] A. Ramadhani, "Identifikasi Nilai-Nilai Karakter Dalam Permainan Anak Tradisional," Journal Prosiding Seminar Nasional IPTEK Olahraga, 2018

[12] I. Fitriani, "Instilling The Local Wisdom In English Language Teaching Through Indonesian Traditional Game," National Seminar Proceeding, 2012

[13] R. Sugiyo, "Local Wisdom-Based Character Education Model in Elementary School in Bantul Yogyakarta Indonesia*," Sino-US English Teaching, vol. 14, no. 5, pp. 299-308, 2017.

[14] P.W. Wijayanto and Y. Siradj, "Designing the Educational Game "The Indonesian Tribes" for Kindergarten Students". National Proceeding. The 3rd Asia-Pacific Education Conference (The 3rd AECon), 2015. 